\title{
Toxicity of Chromium on Nitrogen and Biodegradable Compound Removal in Vertical Flow Constructed Wetlands
}

\author{
H. A Basnayaka and T. Koottatep
}

\begin{abstract}
The objective of this study is to investigate the removal efficiencies of Chromium (Cr), Nitrogen and biodegradable organic compounds, as well as its interference of each other in vertical flow constructed wetlands with different bed media. Four laboratory-scale vertical flow constructed wetland (CW) units, each with dimensions of $750 \times 635 \mathrm{~m}$ (diameter $\times$ height), were installed with different bed media: CWC2 with 200100,100 and $150 \mathrm{~mm}$ of charcoal, sand, small gravel and large gravel; CWC1 with $100,200,100$ and $150 \mathrm{~mm}$ of charcoal, sand, small gravel and large gravel; CWCo and CWControl with 200, 200 and 150 $\mathrm{mm}$ of sand, small gravel and large gravel. Typha Angustifolia (Cattails) were planted at initial density of 50 shoots. $/ \mathrm{m}^{2}$ in $\mathrm{CWC1}, \mathrm{CWC2}$ and $\mathrm{CWC} 0$ units and fed with domestic wastewater spiked with $\mathrm{Cr}$ at the concentrations ranging from 10 to $100 \mathrm{mg} / \mathrm{L}$ at the Hydraulic Retention Time (HRT) of 4 days. Samples from CW units were taken once in 3 days throughout 115 days of operation for analysis of total $\mathrm{Cr}$, nitrogen, $\mathrm{pH}$. In addition, $\mathrm{N}$ accumu lated in the plant biomass (roots and shoots) were analysed to identify the $\mathrm{Cr}$ toxicity for plant uptake of Nitrogen. For influent concentrations up to $30 \mathrm{mg} / \mathrm{L}$, it was found that $\mathrm{Cr}$ mass removal efficiencies for all CW units were $99-100 \%$, resulting effluent concentrations below the industrial effluent standard which is $2 \mathrm{mg} / \mathrm{L}$. Beyond $30 \mathrm{mg} / \mathrm{L}$ influent Cr concentrations, it was apparent that the $\mathrm{CW}$ unit with thick charcoal layer met the industrial effluent standard, even at an influent $\mathrm{Cr}$ concentration of $100 \mathrm{mg} / \mathrm{L}$. Experimental data revealed that the $\mathrm{CW}$ units with charcoal layers could result in COD and N removals of $82-92 \%$ and $57-87 \%$, respectively. Possibly due to the inhibitory effect of $\mathrm{Cr}$ on $\mathrm{N}$ plant uptake, the $\mathrm{N}$ removal in $\mathrm{CW}$ units were decreased rapidly with increasing $\mathrm{Cr}$ loading. On the contrary, the increase in $\mathrm{Cr}$ loading did not affect the $\mathrm{COD}$ removal efficiencies in $\mathrm{CW}$ units.
\end{abstract}

Keywords: Vertical flow Constructed wetlands, Chromium toxicity, COD, Nitrogen

\section{Introduction}

Among the conventional treatment processes, the CWs are found to be efficient in treating industrial wastewater containing chromium due to various treatment mechanisms including biological, physical and chemical interactions of the soil-plant-micro-organisms. Most of the research findings (Gersberg et al ,[7], Oke and Juwarkar [1]) reported that heavy metals such as $\mathrm{Cu}, \mathrm{Cd}, \mathrm{Zn}, \mathrm{Pb}, \mathrm{Ni}$ and $\mathrm{Co}$ could be readily removed by $\mathrm{CW}$ systems though the metal removal efficiency seems to be influenced by the types of media used and the types of wastewater to be treated.

The evaluation of the treatment potential of constructed wetlands appear to have focused separately on two types of pollutants, namely,
a). Biodegradable matters and organic nutrients
b). Toxic pollutant

However the effects of toxic pollutants on removal efficiency of organic compounds as well as nutrients are not yet focused widely among the researches.

Therefore, the goal of this research was to have a better understanding about the effect of $\mathrm{Cr}$ for the performance of nitrogen and COD removals, and to investigate $\mathrm{Cr}$ removal efficiencies with charcoal in the bed media in vertical flow constructed wetlands

Eng. (Ms.) H.A Basnayaka, B.Sc. Eng. (Hons) (Peradeniya) MIE. (Sri Lanka) M.Eng. (AIT), Research Engineer, Lanka Hydraulic Institute ltd

Dr. T. Koottatep, B.Eng. (Chingmai Uninersity, Thailand), M.Eng. and [D.Eng. Associnte Professor in Astan institute of Technology. 


\section{Material and Methods}

Four laboratory scale vertical flow $\mathrm{CW}$ units each with $750 \mathrm{~mm}$ in diameter and $635 \mathrm{~mm}$ in height were employed (Figure 1). Total bed media thickness for all the wetlands were kept as 550 $\mathrm{mm}$ but different bed materials with dissimilar layer thicknesses were employed.
During the start-up period, all $\mathrm{CW}$ units were fed with tap water for two weeks and then fed with domestic wastewater for another two weeks. During this time tracer study was carried out since there was no interference of Lithium ion $\left(\mathrm{Li}^{+}\right)$with domestic wastewater. There the Lithium chloride was injected to make $5 \mathrm{mg} / \mathrm{L}$ of Lithium ion in the inlet, for each $\mathrm{CW}$ unit

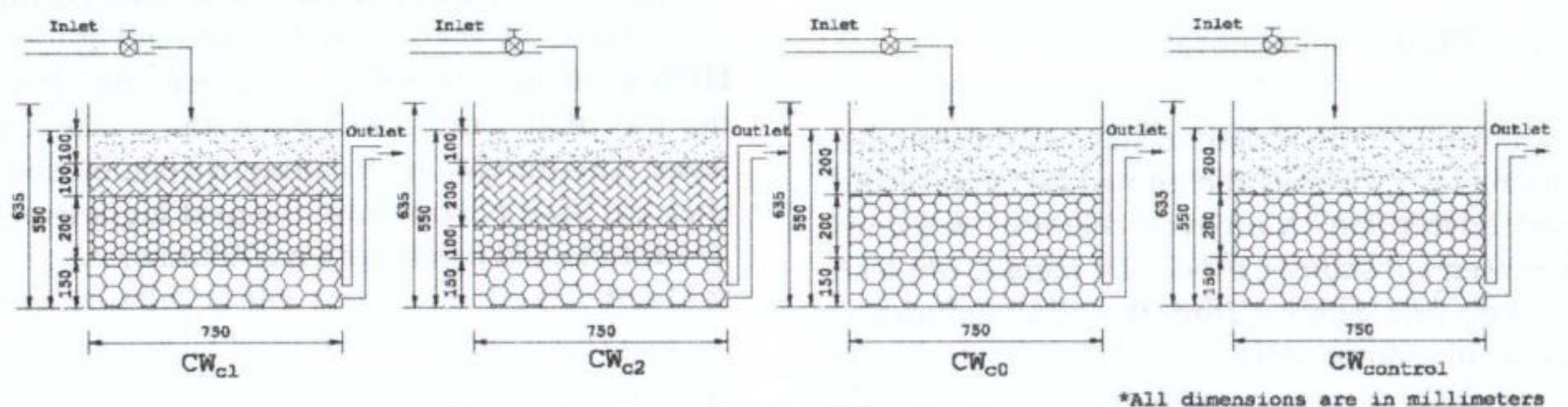

(a)
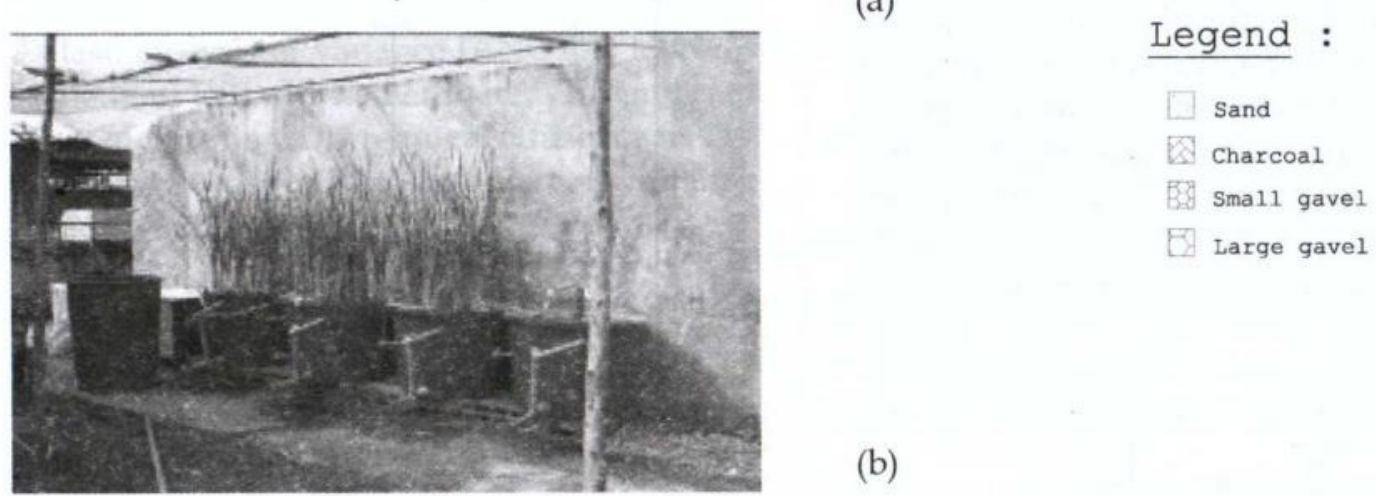

Figure 1- Experimental Setup, (a) Sectional view, (b) Photo in the field

The first $\mathrm{CW}$ unit $(\mathrm{CWC1})$ has a $100 \mathrm{~mm}$ thick charcoal layer (3.36-4 mm media size) in between a sand layer (100 mm thickness with 2-2.38 mm media size) and a small gravel ( $200 \mathrm{~mm}$ thickness with $16-19 \mathrm{~mm}$ media size) layer, which act as chromium adsorbent to enhance the removal efficiency. A $150 \mathrm{~mm}$ thick large gravel (25-37.5 $\mathrm{mm}$ media size) layer was placed under the small gravel layer. Sand (CWC2), charcoal, small gravel and largegravel layers of thickness $100 \mathrm{~mm}, 200 \mathrm{~mm}$, $100 \mathrm{~mm}$ and $150 \mathrm{~mm}$ respectively were employed in the second CW unit from top to bottom. Here the charcoal layer thickness was increased by 100 to see the difference with increased thickness. The third (CWCo) and fourth ( $\mathrm{CW}$ control) $\mathrm{CW}$ units followed the conventional wetland beds with sand and two graded gravel layers. Sand, small gravel and large gravel layer thicknesses were set to 200, 200 and $150 \mathrm{~mm}$ respectively for both of those units. The Cattail plant (Typha Angustifolia) was planted only in the first three $\mathrm{CW}$ units with initial density of 50 shoots $/ \mathrm{m}^{2}$ and the fourth one was employed without plants as a control unit. and effluent Lithium ion concentrations were measured to study the flow pattern inside the $\mathrm{CW}$ units. $5 \mathrm{mg} / \mathrm{L}$ of $\mathrm{Cr}$ concentration was spiked before feeding in the next week to acclimatize the soil microbes and the cattails. After that wastewater with $10 \mathrm{mg} / \mathrm{L}, 30 \mathrm{mg} / \mathrm{L}$ and $100 \mathrm{mg} / \mathrm{L}$ concentrations was fed for 115 days,

The influent and the effluent samples were analysed for total $\mathrm{Cr}, \mathrm{COD}, \mathrm{TN}, \mathrm{NH}_{4}-\mathrm{N}$, $\mathrm{NO}_{2}-\mathrm{N}$, and $\mathrm{NO}_{3}-\mathrm{N}$ in all $\mathrm{CW}$ units once in three days. Experiments were performed under different concentration levels. It was $10 \mathrm{mg} / \mathrm{L}$ at the beginning and increased up to $100 \mathrm{mg} / \mathrm{L}$ stepwise. At last nitrogen uptake by plant was carried out by measuring the nitrogen in the plant components before and after the testing period to find whether there is any effect on $\mathrm{Cr}$ for nitrogen uptake by plant. 


\section{Results and Discussion}

Based on the 115 days of experiential period, the Chromium, COD and nitrogen removals in the wetland system as well as the toxicity of $\mathrm{Cr}$ for removal of COD and Nitrogen is discussed in this section. From the tracer Study it was found that all CW units have the same flow patterns.

\subsection{Chromium removal}

Removal of $\mathrm{Cr}$ in wetlands may occur through a number of processes, including plant uptake and soil adsorption. Moreover chemical reactions between substances, especially metals, can lead to their precipitation from the water column as insoluble compounds.

It was found that $\mathrm{Cr}$ removal efficiency in all $\mathrm{CW}$ units were $99 \%$ when influent $\mathrm{Cr}$ concentration was $30 \mathrm{~m} / \mathrm{L}$. But for high concentrations such as $75 \mathrm{mg} / \mathrm{L}$ the efficiency was remaining above $98 \%$ only in the wetland which had thinker charcoal layer in the bed material. This could be mainly due to the adsorption of $\mathrm{Cr}$ within the charcoal layer ( Figure 2).

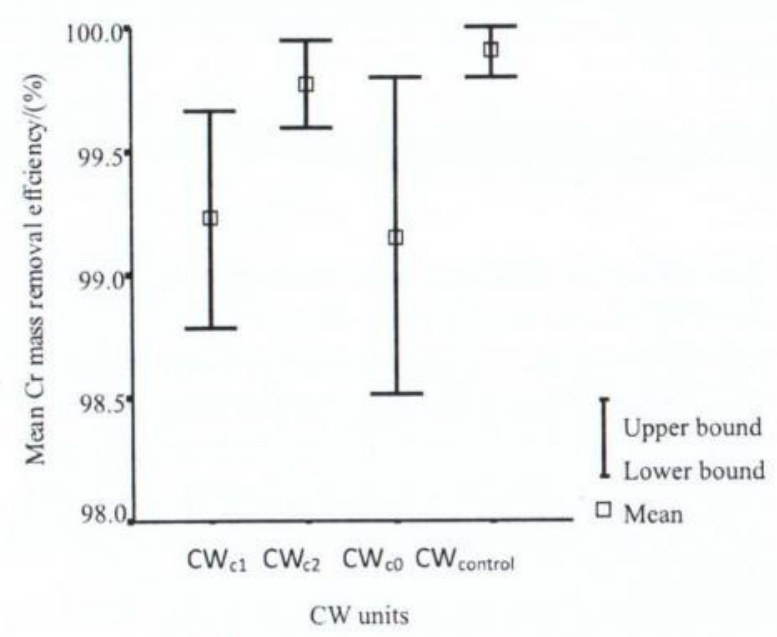

Figure 2- Overall mean $\mathrm{Cr}$ mass removal efficiencies

The overall mean $\mathrm{Cr}$ mass removal efficiencies in $\mathrm{CW}$ units were very high in all $\mathrm{CW}$ units. It was recorded as $99.2 \% \pm 0.44,99.7 \% \pm 0.17,99.1 \% \pm 0.64$ and $99.9 \% \pm 0.11$ in $\mathrm{CWC1}_{\mathrm{C}}, \mathrm{CWC}_{\mathrm{C}}, \mathrm{CWC}_{\mathrm{C}}$ and CWControl respectively. Among the planted $\mathrm{CW}$ units the one with the highest thickness of charcoal layer in the bed media shows the higher removal efficiency of $\mathrm{Cr}$ (Figure 2)

\subsection{COD removal}

An average value of $168 \mathrm{mg}$ / $\mathrm{L}$ was fed during the operation period resulting an average loading rate of $115 \mathrm{~kg}$ of COD/ha.d. Effluent COD concentration in the first two months was same in all the units and afterwards there was a small increment. Mean values of COD mass removal efficiencies in all $\mathrm{CW}$ units were calculated using one sample $\mathrm{T}$ test and it is depicted in Figure 3. Highest mean COD removal was recorded from the $\mathrm{CW}$ unit having a $200 \mathrm{~mm}$ thick charcoal layer $(\mathrm{CWC2})$. $\mathrm{CW}$ unit having a $100 \mathrm{~mm}$ thick charcoal layer $(\mathrm{CWC1})$ gave the next highest and it was followed by other two CW units.

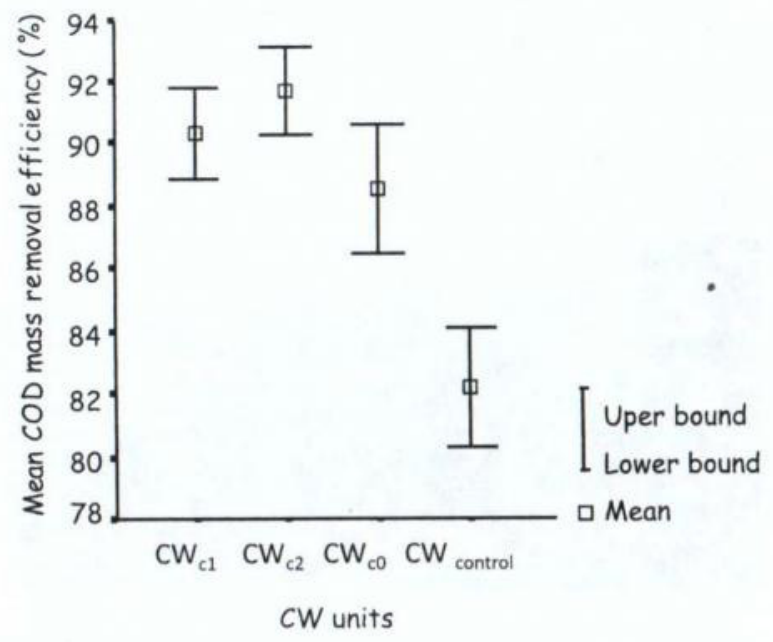

Figure 3- Mean COD mass removal efficiency in CW units

Analysis of Variance (ANOVA) tests were carried out separately for the three cases to see any significant effect on mass removal efficiency of COD. Three planted CW units were taken as a group and the functionality of bed media for COD removal efficiency was considered in the first case (Among these three units two of them have charcoals and the other has only sand and gravel.) It was found that there is a significant effect at $95 \%$ confident interval. Thus it can be said that CW units having charcoal perform differently for COD mass removal. Charcoal could act as adsorption of biodegraded compound and enhance the COD removal in these systems might be the reason.

In the second case two $\mathrm{CW}$ units having different thicknesses of charcoal layer were considered. Different thicknesses of charcoal layer in the wetland bed were not different in COD removal efficiencies, for $95 \%$ confident interval. Hence 
variation of charcoal layer thickness may not affect the COD removal efficiency. In the third case, two CW units having same bed media were considered (CWCo and CWControl), to see whether there was a significant effect with and without plant in treating COD. Treating COD with and without plant in the $\mathrm{CW}$ unit was different for 95\% confident intervals. As Figure 3 shows mean mass removal efficiency of these two were only different by $6 \%$. Recently Chi-Yuan Lee et al [2] found that (52-74\%), and (26-48\%) from the overall removal of COD were due to physical and biological mechanisms respectively. Since charcoal is a good absorbent COD removal efficiency can increase by physical mechanisms. This should be the reason for higher removal efficiency of COD in the $\mathrm{CW}$ units with charcoal layers.

At last, analysis of variance (ANOVA) test was carried out to find whether there is a significant effect of time on COD removal efficiency in CW units and it was found to be different with time for $95 \%$ confidence interval.

\subsection{Nitrogen Removal}

There was no difference in effluent TN in planted CW units for first 40 days and it was closer to zero. After 40 days it increased rapidly. In contrast unplanted CW unit had high effluent loading rate from the beginning and it was same even after 40 days. Nitrogen plant uptake was high until it became mature. That was the main reason to have very less $\mathrm{TN}$ in the effluent within first 40 days.

The highest $\mathrm{TN}, \mathrm{TKN}, \mathrm{NH}_{4}-\mathrm{N}$, Organic-N, $\mathrm{NO}_{3}-\mathrm{N}$ and $\mathrm{NO}_{2}-\mathrm{N}$ were recoded from $\mathrm{CWC0}$ unit. Those values were $79 \%, 79 \%, 82 \%, 69 \%$, $71 \%$, and $80 \%$ respectively. CWC2 unit was the next and it was followed by $\mathrm{CWC1}$ unit and then fourth (WContral) as shown in Table 1. There was high removal efficiency in inorganic nitrogen compound such as $\mathrm{NH}_{4}-\mathrm{N}, \mathrm{NO}_{2}-\mathrm{N}$ rather than organic nitrogen compound.

Because cattail plant readily uptake by inorganic-nitrogen compounds. Thus Organic nitrogen can be removed mainly by microbial actions. As suspended or attached growth microbial organisms play a significant role in biodegradation process of the $\mathrm{CW}$ units, the emergent plants provide supports of the boifilm growth and releases oxygen via the root system.
(Reed et al.,[8], Polprasert et al.,[6]). TKN removal efficiency depends on both $\mathrm{NH}_{4}-\mathrm{N}$ and organic $-\mathrm{N}$ contents. Table 1 shows that removal efficiency of $\mathrm{NH}_{4}-\mathrm{N}$ is higher than that of organic- $\mathrm{N}$. Thus $\mathrm{NH}_{4}-\mathrm{N}$ removal is highly affected for TKN removal efficiency rather than organic-N.

\subsection{Nitrogen Plant Uptake}

Biomass of each CW units, after 4 months period were found to be $49.10,58.94$ and 64.53 ton / ha in $\mathrm{CWC1}_{\mathrm{C}} \mathrm{CWC}_{\mathrm{C}}$ and $\mathrm{CW} 0$ respectively. It was 10.68 ton/ha for the initial period. Roots and leaves plus stem were separately analyzed for $\mathrm{TN}$ in each CW unit by taking two plants per CW unit. Results are illustrated in Table 2 below. It shows that Root and leaves took $1.4-1.92 \%$ and $8.7-10.5 \%$ of TN respectively and came up with a total TN uptake of $10-12 \%$ from the TN input. Breen [5] studied nitrogen mass balance in vertical flow CW units fed with domestic wastewater and reported $55 \%$ of nitrogen uptake by cattail plant. Compared to this value $(55 \%)$, obtained $\mathrm{TN}$ uptake by plants in this study (10-12\%) was very small since $\mathrm{Cr}$ in the inlet was greatly affected.

\subsection{Effect of $\mathrm{Cr}$ for nitrogen uptake by cattail.}

The dry biomass and TN content in the cattail plants at the initial period (before spiked $\mathrm{Cr}$ ) of operation and after four months of operation were analysed. Accumulated nitrogen in Cattail plants and its uptake rates by the plants in all three wetlands are shown in Table 2.The data shows the estimated nitrogen uptake rates as $1.4-2 \mathrm{~kg} / \mathrm{ha} /$ day for all the CW units which received wastewater containing $\mathrm{Cr}$. This range is lower than those reported $\mathrm{CW}$ units treating only the domestic wastewater $4.5-4.9 \mathrm{~kg} / \mathrm{ha} /$ day (Lim et al., [4]), $3.0 \mathrm{~kg} / \mathrm{ha} /$ day (Koottatep and Polprasert, [9]) and $1.6-7.2 \mathrm{~kg} / \mathrm{ha} /$ day(Reddy and DEBusk,1987). Hence $\mathrm{Cr}$ exerted some inhibitory effect on the uptake on nitrogen by cattail plant.

Variation of $\mathrm{COD}$ and $\mathrm{NH}_{4}-\mathrm{N}$ efficiencies with respect to the spiked $\mathrm{Cr}$ concentration in each $\mathrm{CW}$ unit are depicted in Figure 4 above. These results illustrate that, for all $\mathrm{CW}$ units, there was a slight decline of COD removal efficiency in the high $\mathrm{Cr}$ concentration $(100 \mathrm{mg} / \mathrm{L})$. However, for less Spiked $\mathrm{Cr}$ concentrations, there was no observed effect on the COD removal efficiency. 
Table 1- Nitrogen removal efficiencies

\begin{tabular}{|l|r|r|r|r|r|r|r|r|}
\hline & \multicolumn{2}{|c|}{$\mathrm{CW}_{\mathrm{C} 1}$} & \multicolumn{2}{c|}{$\mathrm{CW}_{\mathrm{C} 2}$} & \multicolumn{2}{c|}{$\mathrm{CW}_{\mathrm{C} 0}$} & \multicolumn{2}{c|}{$\mathrm{CW}_{\text {Control }}$} \\
\cline { 2 - 9 } & $\begin{array}{c}\text { Mean } \\
(\mathrm{mg} / \mathrm{L})\end{array}$ & $\begin{array}{c}\text { Removal } \\
(\%)\end{array}$ & $\begin{array}{c}\text { Mean } \\
(\mathrm{mg} / \mathrm{L})\end{array}$ & $\begin{array}{c}\text { Removal } \\
(\%)\end{array}$ & $\begin{array}{c}\text { Mean } \\
(\mathrm{mg} / \mathrm{L})\end{array}$ & $\begin{array}{c}\text { Removal } \\
(\%)\end{array}$ & $\begin{array}{c}\text { Mean } \\
(\mathrm{mg} / \mathrm{L})\end{array}$ & $\begin{array}{c}\text { Removal } \\
(\%)\end{array}$ \\
\hline $\mathrm{TN}$ & 6.99 & $69 \pm 9$ & 5.13 & $77 \pm 7$ & 4.76 & $79 \pm 8$ & 11.09 & $45 \pm 5$ \\
$\mathrm{TKN}$ & 6.63 & $70 \pm 10$ & 4.85 & $77 \pm 7$ & 3.88 & $79 \pm 8$ & 10.63 & $45 \pm 5$ \\
$\mathrm{NH}_{4}-\mathrm{N}$ & 3.97 & $73 \pm 11$ & 3.06 & $79 \pm 9$ & 2.33 & $82 \pm 9$ & 6.71 & $51 \pm 7$ \\
Organic-N & 2.66 & $58 \pm 9$ & 1.77 & $69 \pm 10$ & 1.55 & $69 \pm 8$ & 3.92 & $30 \pm 5$ \\
$\mathrm{NO}_{3}-\mathrm{N}$ & 0.22 & $50 \pm 10$ & 0.19 & $55 \pm 11$ & 0.12 & $71 \pm 9$ & 0.22 & $48 \pm 11$ \\
$\mathrm{NO}_{2}-\mathrm{N}$ & 0.06 & $67 \pm 8$ & 0.04 & $74 \pm 06$ & 0.03 & $80 \pm 5$ & 0.06 & $58 \pm 14$ \\
\hline
\end{tabular}

Table 2- Plant uptake rate of Nitrogen

\begin{tabular}{|c|c|c|c|c|c|c|c|c|c|c|c|c|}
\hline \multirow{3}{*}{ Consortium } & \multirow{2}{*}{\multicolumn{3}{|c|}{$\begin{array}{l}\text { Initial period (Before } \\
\text { spiked chromium) }\end{array}$}} & \multicolumn{9}{|c|}{ 4- months after } \\
\hline & & & & \multicolumn{3}{|c|}{$\mathrm{CW}_{\mathrm{C} 1}$} & \multicolumn{3}{|c|}{$\mathrm{CW}_{\mathrm{C} 2}$} & \multicolumn{3}{|c|}{$\mathrm{CW}_{\mathrm{C} 3}$} \\
\hline & leaves & root & total & leaves & root & total & leaves & root & total & leaves & root & total \\
\hline Dry & 6 & 4 & 11 & 37 & 12 & 49 & 49 & 10 & 5 & 52 & 1 & 64 \\
\hline (ton/ha) & 0 & 4 & 11 & 3 & 12 & 47 & 47 & 10 & 39 & & & \\
\hline $\begin{array}{l}\mathrm{N} \text { content } \\
\text { (kg/ton) }\end{array}$ & 5 & 3 & - & 5 & 4 & - & 4 & 4 & - & 3 & 3 & - \\
\hline $\begin{array}{l}\text { N storage } \\
\text { ( kg/ ha) }\end{array}$ & 33 & 14 & 48 & 172 & 45 & 217 & 200 & 37 & 236 & 177 & 42 & 220 \\
\hline \multicolumn{4}{|c|}{$\begin{array}{l}\mathrm{N} \text { plant uptake rate } \\
\text { (kg/ha.4month) }\end{array}$} & 139 & 30 & 169 & 167 & 22 & 189 & 144 & 28 & 172 \\
\hline \multicolumn{4}{|c|}{$\mathrm{N}$ plant uptake rate $(\mathrm{kg} /$ (ha. day) } & 1.16 & 0.25 & 1.41 & 1.39 & 0.19 & 1.57 & 1.20 & 0.23 & 1.44 \\
\hline \multicolumn{4}{|c|}{$\%$ of $\mathrm{TN}$ input } & 8.72 & 1.92 & 10.63 & 10.48 & 1.40 & 11.88 & 9.08 & 1.76 & 10.84 \\
\hline
\end{tabular}

Average

TN input $=13.25 \mathrm{~kg} /$ ha.day

$\mathrm{NH}_{4}-\mathrm{N}$ removal efficiency was observed to be deteriorated rapidly with increasing $\mathrm{Cr}$ concentration in planted $\mathrm{CW}$ units. Among these three units, one with the highest charcoal in the wetland bed ( $\left.\mathrm{CW}_{\mathrm{C} 2}\right)$ gave less deterioration compared to other two. In contrast, gradient of the $\mathrm{NH}_{4}-\mathrm{N}$ with $\mathrm{Cr}$ concentration in unplanted $\mathrm{CW}$ unit (CWControl) was not considerable compared to other three. Thus from the above observations it can be concluded that there is a significant effect on $\mathrm{Cr}$ to plant uptake of $\mathrm{NH}_{4}-\mathrm{N}$ while increasing the $\mathrm{Cr}$ concentration.
Lim et al [4] reported that the efficiency of $\mathrm{NH}_{4}-\mathrm{N}$ removal in both horizontal free water surface and subsurface flow CW systems deteriorated with increasing $\mathrm{Cu}$ loading, whereas the removal efficiency of COD was particularly unaffected. Recently, Lim et al [3] experienced the same results with four lab scale subsurface flow CW units for $\mathrm{Zn}, \mathrm{Pb}$ and $\mathrm{Cd}$ as well. There the range of metal concentration considered was up to10 $\mathrm{mg} / \mathrm{L}$ and flow rate was limited to $25 \mathrm{ml} / \mathrm{min}$ 

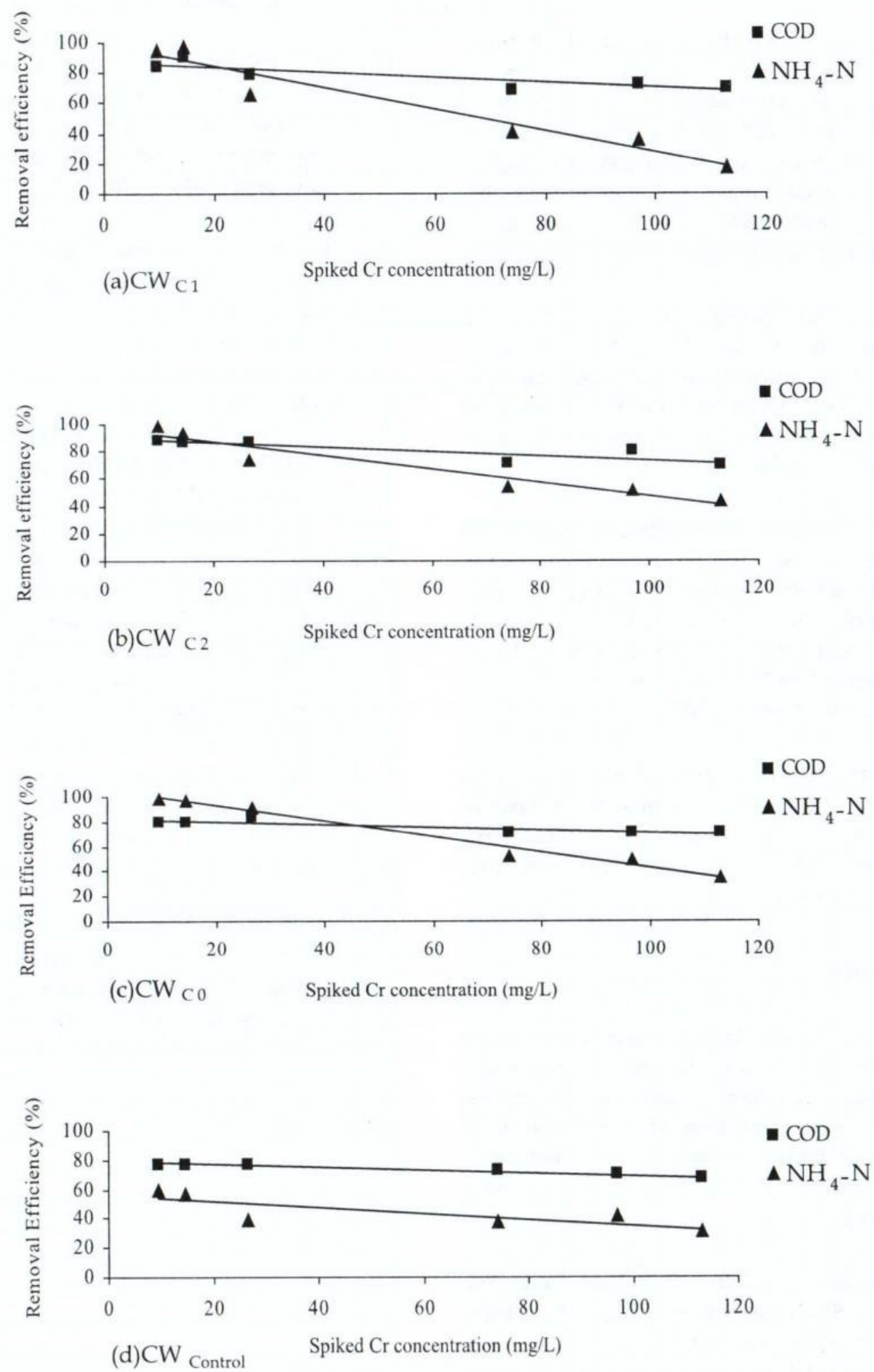

Figure 4 - Variation of $\mathrm{NH}_{4}-\mathrm{N}$ and COD removal efficiencies Vs Spiked $\mathrm{Cr}$ 


\section{Conclusions}

Based on the findings of this study, following conclusions can be drawn:

- $\quad \mathrm{CW}$ units which consisted of charcoal layers as wetland bed material, perform differently in treating COD. Further both CW units with thick and thin charcoal layers in the bed media gave the higher mean COD mass removal efficiencies, $91.7 \%$ and $90.3 \%$ respectively during the experimental period.

- The total nitrogen removal efficiency deteriorated rapidly with increasing Cr. In contrast, there was essentially no observed effect on the COD removal efficiency within the range of the metal loading applied.

- $\quad$ All CW units met $\mathrm{Cr}$ effluent standard of $2 \mathrm{mg} / \mathrm{L}$ when the influent concentration was about $30 \mathrm{mg} / \mathrm{L}$. However among the planted $\mathrm{CW}$ units, the one with thick charcoal layer was tally with effluent standard of $2 \mathrm{mg} / \mathrm{L}$ even for influent $\mathrm{Cr}$ concentration was $100 \mathrm{mg} / \mathrm{L}$.

- Vertical flow constructed wetland is one of the best option in treating industrial wastewater containing $\mathrm{Cr}$ (Tannery, Electroplating etc.. as a secondary treatment process.

\section{References}

1. Oke B.H., Juwarkar A. S" removal of heavy metals from domestic wastewater using constructed wetland system. In: Proceedings of the fifth international conference on wetland systems for water pollution contral. Volume 1 : International Association on water Quality, 1996. pp17-1.

2. Chi-Yuan Lee., Chun-Chih Lee., Fang -Yin -Lee., Szu Kung Tseng and Chiu Jung Liab. "Performance of subsurface flow constructed wetland taking pretreated swine effluent under heavy load" Bio-resource Technology, 2003., 92 (2), 173-179.
3. Lim, P.E., Tay, M.G., Mak, K.Y. and Mohamed, N. ,.Effect of heavy metals on nitrogen and oxygen demand removal in constructed wetlands, The science of the total environment,2003,301, 13-21.

4. Lim, P.E., Wong, T.F. and Lim, D.V. .Oxygen demand, Nitrogen and copper removal by free water surface and subsurface flow constructed wetland under tropical conditions. Environmental Int, 2001,26,423-429.

5. P.F Breen., "A mass balance method for assessing the potential of artificial wetlands for wastewater treatment" Water Resource, 1990. 24 (6), 689-697.

6. Polprasert, C., Khatiwada, N., Brutel, J. . Design modal of COD removal in constructed wetlands based on biofilm activity, Journal of environmental Engineering,1998, 124, (9).

7. R.M Gersberg ,R.S Lyon ,B.V Elkins ,C.R Goldman. " The removal of heavy metals by artificial wetlands. In: Processing of water Symposium 3 on Future of Water Resource. ( San Diego,Califonia) Vol 2, USA:AWWA Research Foundation; 1984. pp 639-648.

8. Reed,S.C., Middlebrooks, E.J. and Crites, R.W., Natural system for wastewater management and treatment, second edition, McGraw-Hill Inc, New York,1998.

9. T. Koottatrp, C.Polprasert.," Role of plant uptake on nitrogen removal in constructed wetlands located in the tropics", Water Science and Technology, 1997:36,PP1-8. 